\title{
QUÈ ÉS LAIREM
}

El LAiREM, "Literatura, Art i Representació a l'Edat Mitjana”, és un Grup de Recerca Consolidat de l'AGAUR (2009 SGR 258) que té per objectiu investigar les relacions entre els textos literaris, la iconografia que sovint els il.lustra en els manuscrits, les expectatives de representació que la tradició interpretativa i consuetudinària han fet arribar fins als nostres dies, la música que solia acompanyar la difusió d'aquests textos i l'espai en que es produïa la seva presentació pública. Això implica tant l'anàlisi dels elements iconogràfics en ells mateixos, com la seva consideració en tant que instruments auxiliars en la comprensió dels textos que il.luminen. Per raons de congruència epistemològica amb els objectes d'estudi i d'acord amb les especialitats dels investigadors del grup, el període històric de referència és l'anomenada per Jacques Le Goff “llarga Edat Mitjana” (Pour un long Moyen Âge, revista Europe, 654, 1983), un temps de creació que si bé configura una estètica forta entre els segles XII i XV (romànic i gòtic), el seu impuls artístic es perllonga fins la caiguda de l'Antic Règim, almenys en la tradició popular i, particularment, en les cultures minoritzades pels Estats absoluts de l'Europa moderna, les quals van seguir fidels a la llengua pròpia i a les formes d'expressió culminades a l'època medieval i mantingudes per tradició com a alternativa a la cultura oficial colonitzadora.

Transversalitat $i$ interdisciplinarietat. Abordar l'estudi de l'Edat Mitjana des de la tradicional compartimentació disciplinària s'ha demostrat menys factible que fer-ho des d'una òptica transversal. El plantejament interdisciplinari que proposem ens ha de permetre copsar les dimensions del fenomen artístic (literari, plàstic, arquitectònic, musical i espectacular), que altrament quedarien ocultes o esbiaixades, amb l'objectiu d'assolir allò que Umberto Eco anomena «una comprensió recta i simpatètica de la inclinació medieval al suprasentit i a la significació indirecta" (Art i bellesa en l'estètica medieval, Barcelona, 1990, p. 195).

Text literari. D'una banda tenim el text literari que, en l'època medieval, sovint és polivalent (Paul Zumthor, La letra y la voz. De la "literatura" medieval 1987: 267-32I) i deixa un gran marge de llibertat a adaptadors i executants, de manera que podia ser llegit, declamat, recitat en forma dialògica o fins i tot interpretat o representat escènicament, una mica segons l'ocasió, les condicions puntuals (festives, litúrgiques, commemoratives, etc.) i les disponibilitats tècniques, materials i humanes del moment i del lloc. El nostre grup de recerca considera, doncs, els textos medievals en la seva naturalesa fonamentalment performativa, és a dir que la difusió o "publicació" de la matèria literària comportava sovint una 'posada en escena' davant d'un auditori que moltes vegades no tenia cap 
altre mitjà d'accedir als continguts d'aquests textos. En una societat basada en l'oralitat com la de l'Edat Mitjana, i fins i tot la postmedieval almenys fins la revolució industrial, la transmissió de continguts es realitza principalment de viva veu, reservada la lectura silenciosa a una élite. Això comporta una dimensió pública en la recepció d'aquells continguts, necessàriament impregnada d'elements performatius que sovint afecten a la mateixa composició del text.

Imatge. Pel que fa a la imatge plàstica recordem que, més que cap altre tipus de societat, "les societats medievals foren civilitzacions visuals." (Jean Duvignaud Sociología del Teatro. Ensayo sobre las sombras colectivas, Mèxic, I966, p. I03). L’art medieval, propens a recórrer a l'ambigüitat figurativa amb intenció semàntica, formula un pensament figural i universalista de tall cristià, que no podem arribar a copsar en tota la seva dimensió sense la profícua relació amb els textos literaris als quals sovint la imatge acompanya o s'hi fa acompanyar.

Espai. Pel que fa a l'espai arquitectònic on es desenvolupa l'activitat artística, litúrgica, musical i rítica, es pretén reconstruir un escenari, el de la litúrgia cristiana entesa en el seu marc arquitectònic, amb la seva tramoia i attrezzo, a través de l'estudi heurístic de les fonts litúrgiques de les catedrals i la seva relació amb la seva construcció tectònica, la seva circulació cerimonial i la integració del temple en el seu mitjà urbà mitjançant els ritus estacionals.

Música. A l'Edat Mitjana, l'esplendor plàstic i l'eixarm auditiu de la música eren les millors armes per arribar a la gent. El suport melòdic amb què se servien la majoria dels textos èpics, lírics i dramàtics serà, doncs, l'altre pilar fonamental de la recerca del grup.

Metodologia. Una investigació, doncs, interdisciplinària, que ha de posar en joc metodologies provinents de la història de l'art (des de l'arquitectura a la música, passant per la plàstica i les tècniques anomenades "decoratives"), la història i la teoria literària, la història del pensament i les mentalitats, l'antropologia cultural, la teoria i la pràctica teatrals... I sempre provant de formular noves qüestions per extreure'n nous resultats, perquè, com deia Giovanni Levi, "la història és la ciència de les preguntes generals i de les respostes particulars".

Es tracta d'evitar el perill de projectar sobre els fenòmens artístics medievals les modernes categories culturals. Només amb una mirada polièdrica podem assegurar-nos el respecte per la lògica interna d'aquestes manifestacions, en la línia apuntada per Eco quan diu: "Quan algú prova de fer una història de l'estètica medieval és per tractar d'explicar com pensaven els medievals, no pas com pensem nosaltres o com hauríem de pensar".

L'eix que articula la recerca transversal del grup són les creacions literàries i artístiques i els seus peculiars mecanismes de transmissió i difusió en un context com el medieval condicionat per l'espai (arquitectònic, urbanístic) en què les 
manifestacions es feien públiques, i pel temps (zodiacal, cerimonial, festiu, polític) en què es produïen.

En aquest sentit hi ha quatre línies d'actuació, segons el marc de realització de l'activitat creativa: l'espai catedralici, l'espai conventual, l'espai cortesà $\mathrm{i}$ l'espai urbà.

\section{i. Producció artístico-literà}

Així, entre els projectes concrets que s'endegaran hi ha l'estudi de les cerimònies i actes dramàtico-litúrgics propis de les grans catedrals hispàniques, un nucli de treball que implica la investigació de l'arquitectura i la litúrgia de Eduardo Carrero (UIB), la dimensió espectacular i tramoística de Francesc Massip (URV) i la columna sonora sobre la que se sostenien aquests actes de Maricarme Gómez Muntané (UAB). Les fonts de partida principals són les Consuetes catedralícies, és a dir els llibres que descriuen els ritus desenvolupats en una església durant l'any litúrgic, molts d'ells amb dimensió espectacular. Particularment a les Catedrals de Girona, Ciutat de Mallorca, Tarragona, Lleida, València, etc., amb arxius que custodien Llibres d'Obra i Fàbrica, documentació on abunden las referències a despeses en materials, preparatius, construccions i reparacions relatives a representacions paralitúrgiques. Seguint el calendari litúrgico-estacional, hi ha d'una banda la celebració de la Nativitat de Crist i tot el cicle d'hivern quan aquests espais eren usats i freqüentats per una densa xarxa d'actes. Des de la vigília de Nadal fins a l'Epifania es documenten quatre tipus de manifestacions integrades en els oficis litúrgics d'arreu d'Europa: l'Officium pastorum, o visita dels pastors al pessebre; l'Ordo prophetarum o anunci de la vinguda del Messies per part de profetes, d'on es destaca la Sibil.la i el seu Cant estremidor; l'Ordo Rachelis o plany de Raquel per la matança dels seus fills (degolla dels Innocents) i l'Ordo o Officium stellae, amb l'arribada dels Mags, guiats per l'estrella, i la seva adoració de l'infant Jesús. Menció especial mereixeria els actes a l'entorn del Bisbetó, dignitat efímera escollida entre els escolans que comportava un ús peculiar de l'espai arquitectònic durant el seu mandat d'inversió ritual. L'altre moment àlgid és la Setmana Santa i la rememoració de la Passió, Mort i Resurrecció de Crist, un dels episodis crucials de l'imaginari medieval, que és objecte de la recerca principal de Lenke Kovács (URV), que acaba de finalitzar una tesi doctoral sobre el tema dirigida pel coordinador del grup, amb qui ha desenvolupat una continuada col-laboració de recerca en els últims anys. Del cicle estival, destaca l'Assumpció de Maria, una festivitat a l'entorn de la qual es van generar multitud d'actes i produccions artístiques de les quals n'han quedat expressives traces, particularment amb el Misteri d'Elx, objecte d'una tesi doctoral de la investigadora coreana Hye Kyung Jeong, dirigida per F. Massip. 


\section{Producció artístico-Literària EN L'ESPAi CONVENTUAL}

Encara que també de naturalesa eclesiàstica, presenta tota una altra problemàtica l'espai conventual, que centra la recerca d'Almudena Blasco (UAB) i Rebeca Sanmartín (UCM), ocupades en destriar la creativitat literària i artística en el reservat àmbit femení que darrerament està oferint notables sorpreses, com les cerimònies i polifonies nadalenques de les clarisses d'Astudillo descobertes i publicades per Pedro M. Cátedra (Liturgia, poesía y teatro en la Edad Media, Madrid, 2005). Rebeca Sanmartín acaba d'analitzar la complexa expressió de l'espiritualitat femenina tardomedieval i protorenaixent en el llibre La representación de las misticas: Sor María de Santo Domingo en su contexto europeo (Santander, Estudios Ensayos Ediciones Propileo 2012).

\section{Producció artístico-literària en l'espai cortesà}

L'espai cortesà convoca la recerca a l'entorn de la producció artística i literària en l'àmbit privat del palau (reial o feudal), particularment l'activitat de trobadors i joglars, poetes cancioneriles, o novel-lística àulica com el Jauffre i la Flamenca, així com obres plàstiques de clara significació política com el sostre pintat del palau dels Steri de Palerm, raïm temàtic en el qual treballen Costanzo Di Girolamo (UNapoli), Camilo Fernández (UB), Licia Buttà (URV), Anton Espadaler (UB), Llívia Palliso (URV) i Donatella Siviero (UMessina).

\section{Producció artístico-literària en l'espai urbà}

És en l'espai urbà on es produeix una laïcització de la cultura medieval i on es perfila una professionalització dels seus creadors. En aquesta senda circula la recerca de Sandra Pietrini (UTrento), que vol aprofundir la teatralitat profana medieval a través d'un recorregut comparatiu de la imatge dels entretenidors a l'Europa dels segles XII al XVII, posant sobre la taula algunes analogies significatives i permanències. Mitjançant l'anàlisi comparativa dels diversos contextos literaris i figuratius, la recerca pretén contribuir a la definició i a l'evolució del concepte d'actor des de l'època tardomedieval a la moderna, amb particular atenció a les seves reincidències iconogràfiques. També Francesc Massip (URV) per la definició de l'actor tardomedieval que, en l'àmbit urbà i a redós dels gremis o confraries dels oficis, comença a agrupar-se en incipients companyies i a proveirse dels seus propis textos per recitar. El predicador s'apropia de l'espai (plaça) i les tècniques de l'intèrpret per fer més eficaç la seva missió edificant. La retòrica i el teatre d'evangelització centra la recerca d'Oscar A.García Gutiérrez (UNAM), medievalista format a Bèlgica (Louvaine) i aplicat a l'estudi de l'arribada al Nou Món de les estratègies edificants pròpies de la cerimònia espectacular de l'Edat Mitjana europea, i, concretament, al Mèxic del s. xvI, on no només es localitzen 
referents formals i literaris del teatre medieval traduïts a les llengües indígenes, sinó també pervivències tradicionals de llarg recorregut, que sovint són susceptibles de posar en relació amb aspectes de les tradicions populars europees, i que posen de manifest l'exitós procés de mestissatge. En l'àmbit de la iconografia medieval s'ha incorporat recentment al Grup la investigadora Licia Buttà (URV), especialista en les representacions plàstiques en l'espai laic (palaus) o en les representacions de tipus laic en l'espai sagrat (sostres pintats d'esglésies, iconografia de la dansa, etc.). 